\title{
山形市「沼の辺」貯水池の湖沼学的研究
}

\author{
(插図 1 9)
}

加藤 武 雄

\section{A limnological investigation of the artificial lake \\ "Numa-no-be", Yamagata City \\ By Takeo KaTō}

\author{
1. 緒言
}

「沼の辺」眝水池は山形市市街地の北東部すなわち東経 $140^{\circ} 22^{\prime}$, 北緯 $38^{\circ} 12^{\prime}$ 飞位置す る人造湖で，その湖面標高は約 $140 \mathrm{~m}$ である. 湛水する以前には湖底の西半部が水田に利 用されていたが，もともと法湿地带で，をこには二，三の涌泉も見られた．灌䫀の目的か ら，1943〜1947年に北部に築堤し，東部山地をトンネルで貫いて大網沢の水をここに導入 した．「沼の辺」貯水池はこのように造成されたもので，まだ20年ほどの歴史しかもたな い. 現在は観光地の一つになつている.なお，この湖の東，西，南の三方が低い山地で囲 まれ，湖岸には石英粗面岩がとこるどころに露出する，筆者は，このように歴史の若い人 造湖がどのような湖沼学的特徴をもつが知るために，まず一年間における湖水の水質変 化に重点を㧊いて1963年より調查を行なつてきた。ここではこれまでに得られた結果につ いて報告する。

\section{2. 湖 盈 形 態}

1964年 4 月10日，この湖について測量・鋌测を行ない図1のような深度図を得た。これ から求めた湖盈形態の諸計測値を表 1 亿かがゲる. 湖岸線の長さ $926 \mathrm{~m}$, 最大深度 $7.40 \mathrm{~m}$ の湖沼である.南部において陸地が湖沼に桇出しているので肢節量柱多少大きく 1.27 に

表 1 湖盆形態諸計測値表

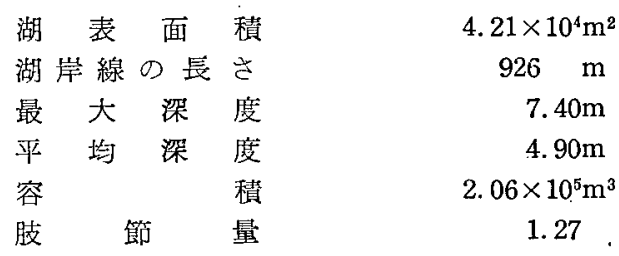




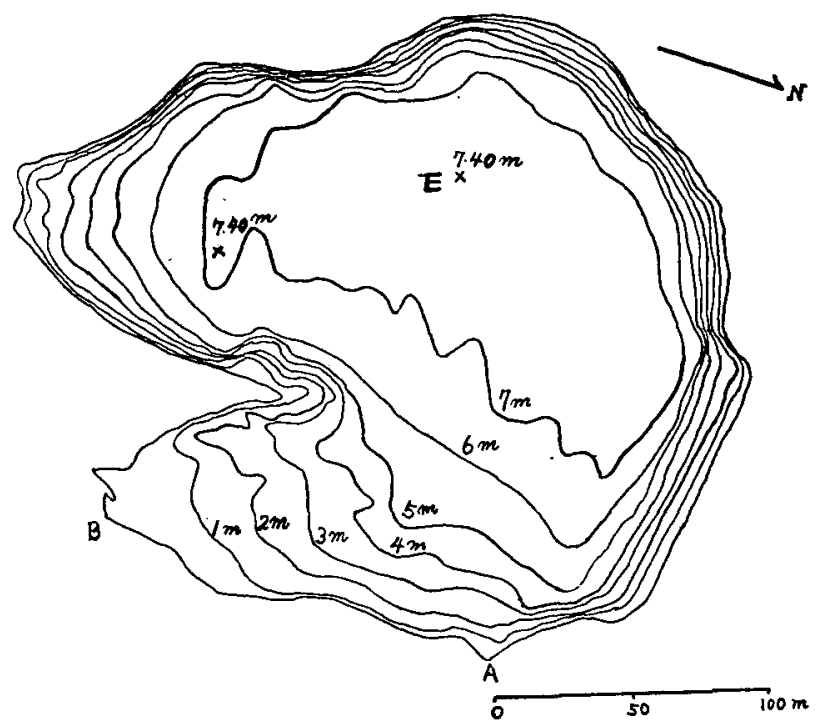

図 1. 潹度図

なつている. 図中のA点は大絸沢からの引水の注入点で常時流入する. B点も小沢の注入 口であるが，瀜雪・降水時以外流量が少なくてほとえど問題にならない。

\section{3. 湖水の理化学的性質}

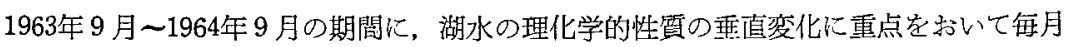
調查を行なつた。観測定点として最深点に当る $\mathrm{E}$ 点（図 1 ）学選えだ. 水質観測の要領は これまでと同様に国土調查法の水質調查作業規程準則（総理府，1957）により，他の諸测 定注西条 (1957) に従つた。

\section{1 湖表水の水質}

はじめに1964年8月の湖表水について化学組成を検討してみよう。すなわ名，おもなカ テオンとして $\mathrm{Na}^{+}, \mathrm{K}^{+}, \mathrm{Ca}^{2+}, \mathrm{Mg}^{2+}$; アニオンの代表として $\mathrm{Cl}^{-}, \mathrm{SO}_{4}{ }^{2-}, \mathrm{HCO}_{3}{ }^{-}$を選び, 各イオン群ごとに当量百分率を計算した結果を key diagram（村下，1963）に表現する. これは図 2 としてかかげたがここには比較のために筆著の調查した二，三の湖沼の資料 (1965) も載せてある。まず，当量関係はカチオンでは $\left.\mathrm{Na}^{+}>\mathrm{Ca}^{2+}\right\rangle \mathrm{K}^{+}$, アニオンでは $\mathrm{HCO}_{3}{ }^{-}>\mathrm{SO}_{4}{ }^{2-}>\mathrm{Cl}-$ が成り立つ. 内陸の湖沼では $\mathrm{Ca}^{2+}>\mathrm{Na}^{+}$の場合が多く，この湖水恃 異である. 図 2 から，この湖表水の主成分はナトりウム，カルシウムの重炭酸塩，硫酸塩 


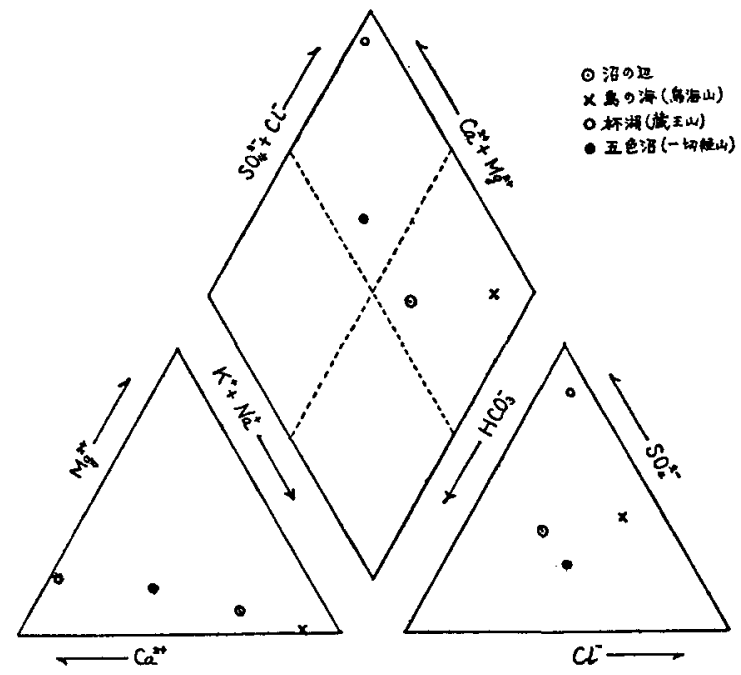

図 2. 主要成分についての key diagram

と半断される.

$\mathrm{pH}$ について見ると，10〜3月の期間では湖表水はほぼ中性完呈するが，4〜9 月の期間で

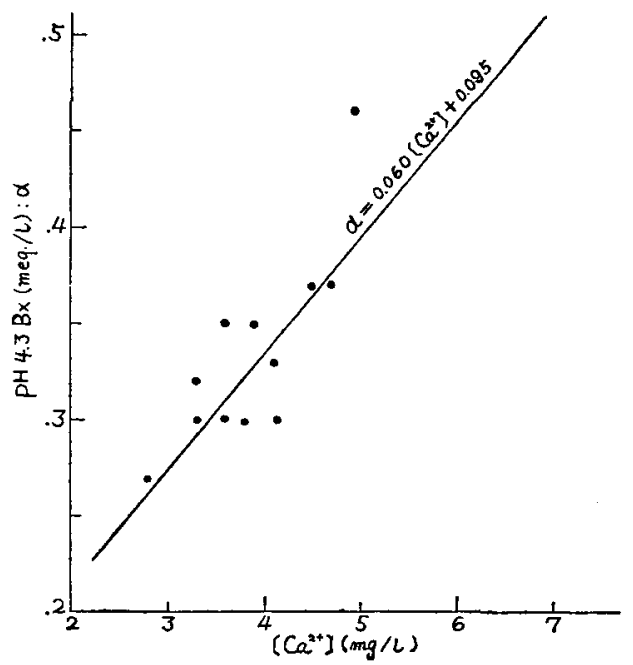

図 3. $\left[\mathrm{Ca}^{2+}\right]-\mathrm{pH} 4.3 \mathrm{Bx}$ 相関図 (湖表水) 
注 5,6月を除くと $\mathrm{pH} 8.0$ 以上のアルカリ性となる. A点小らの流入水は年間最高で $\mathrm{pH}$ $=7.3$ を示可に過ぎないら，4月からの $\mathrm{pH}$ の急增は流入水が湖沼に入つてからの二次

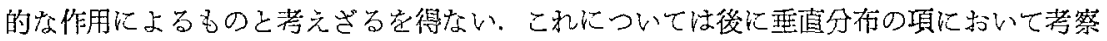
したい.

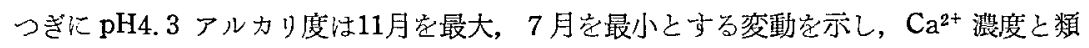

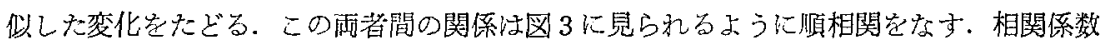
は 0.859 で $1 \%$ 水準にて有意である. $\mathrm{Ca}^{2+}$ 濃度 $\left[\mathrm{Ca}^{2+}\right](\mathrm{mg} / \mathrm{l})$ に関する $\mathrm{pH} 4.3$ アル カリ度 $\alpha(\mathrm{meq} / \mathrm{l})$ の回帰方程式はつぎのよに尔.

$$
\alpha=0.060\left[\mathrm{Ca}^{2+}\right]+0.095
$$

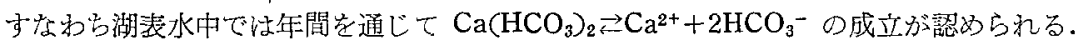

3.2 理化学的性質の更直変化

はじめに水温の季節変化のようす学図 4，5に示して，いるいろ㮔討を試みる。これら

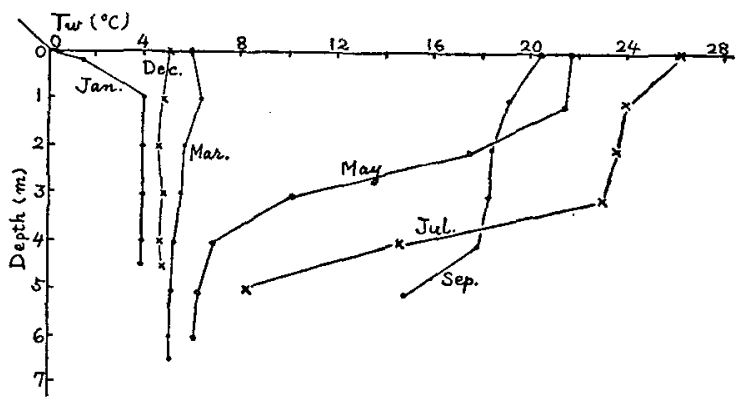

図 4. 季節による水温成圆の推移.

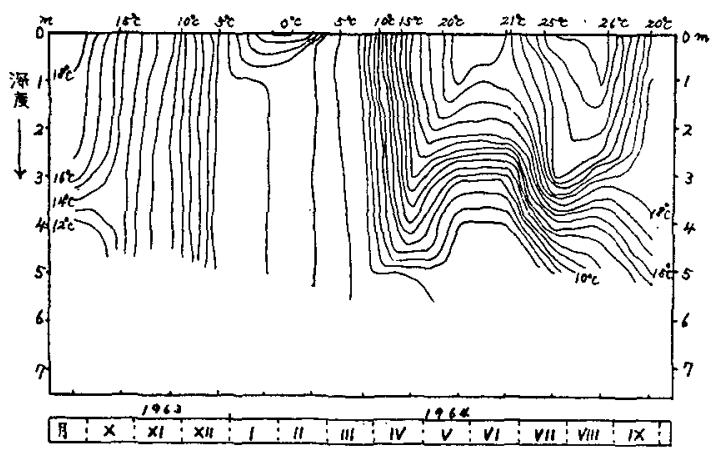

図 5. 水温の季節変化 
によると，4月下旬から 8 月下旬までの期間が复季の停㴖期と見られ，とくに 5 月上旬か ら6月下旬に加けて02 カ月間定完全停滞期と見てよい。つきに8月下旬方ら10月上旬に かけて夏李部分循環期に当る。 そ狆から12月末にかけて秋季完全循環期に相当する，1月 上旬より 3 月上甸にかけての期間では湖表面が氷結して水温の逆列成間がわずかではある

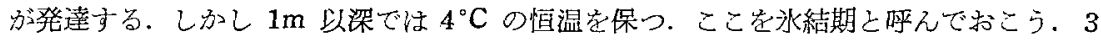
月上旬から 4 月中旬にかけては全風にわたつて不安定で水温の鉛直傾度もき⿰かて小さく，

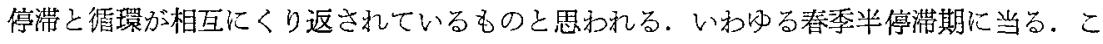
のように水温の年変化から㒻るとこの湖はHUTCHINSON (1957) の第 2 級の湖沼に相当する.

つぎに $\mathrm{pH}$ および溶存酸素飽和度に関する季節変化を考えていこう，てれらについては 図6,7 に図示してある.いずれの場合も全体としては水温と呼心した類似の傾向定示与.

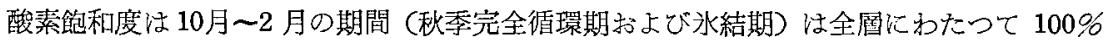
に達することなく，3 月上旬になつて 100\%になる。この時期から9月にかけて表水層は

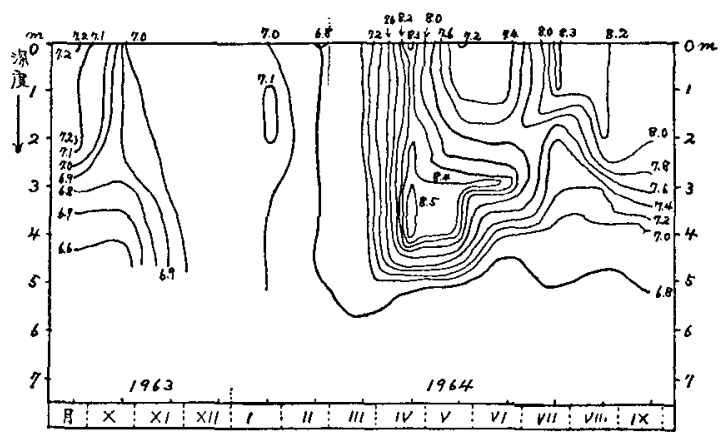

図 6. $\mathrm{pH}$ の季節変化

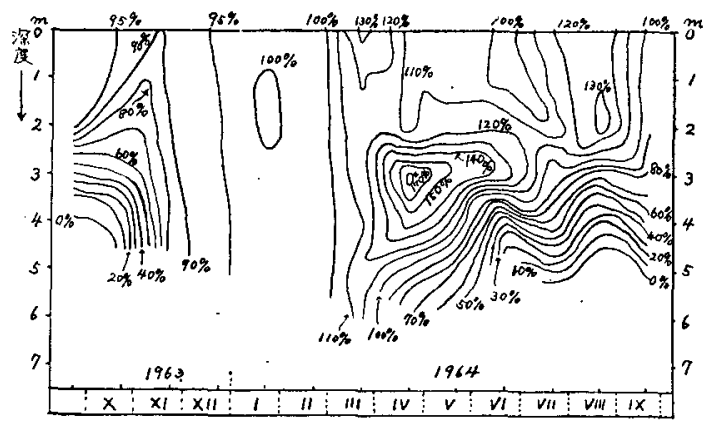

図 7. 溶存酸素飽和度の季節変化 
表 2 山形市沼の辺聍水池水筫分析表 $(1964 . V-20)$ 透明度 $=1.87 \mathrm{~m}$

\begin{tabular}{|c|c|c|c|c|c|c|c|c|c|}
\hline $\begin{array}{l}\text { 深度 } \\
(\mathrm{m})\end{array}$ & $\begin{array}{l}T_{W} \\
\left({ }^{\circ} \mathrm{C}\right)\end{array}$ & $\mathrm{pH}$ & $\mathrm{RpH}$ & $\begin{array}{c}\text { Ré } \\
(\mathrm{ppm})\end{array}$ & $\begin{array}{r}\mathrm{DO} \\
\mathrm{O}_{2}(\mathrm{ppm})\end{array}$ & $\mathrm{O}_{2}(\%)$ & $\underset{(\mathrm{me} / l)}{\mathrm{pH} 4.3 \mathrm{Bx}}$ & $\underset{(\mathrm{me} / l)}{\mathrm{pH} 8.4 \mathrm{Ax}}$ & $\begin{array}{l}\mathrm{Na}^{+} \\
(\mathrm{ppm})\end{array}$ \\
\hline 流入水 $\mathrm{A}$ & 12.1 & 7.1 & 7.1 & 76 & 10.16 & 97.6 & 0.330 & 0.029 & 7.1 \\
\hline 0 & 21.6 & 7.2 & 7.0 & 60 & 8.99 & 104.7 & 0.300 & 0.029 & 6.7 \\
\hline 1 & 21.5 & 7.3 & 7.1 & 56 & 8.94 & 103.8 & 0.296 & 0.029 & 6.7 \\
\hline 2 & 17.6 & 7.8 & 7.3 & 58 & 10.78 & 116.3 & 0.296 & 0.019 & 6.6 \\
\hline 3 & 10.1 & 8.4 & 7.8 & 53 & 15.72 & 144.2 & 0.287 & 0.00 & 6.6 \\
\hline 4 & 6.7 & 8.4 & 7.4 & 61 & 14.22 & 120.7 & 0.284 & 0.00 & 6.7 \\
\hline 5 & 6.2 & 6.8 & 7.1 & 63 & 8.82 & 73.4 & 0.305 & 0.058 & 6.7 \\
\hline 6 & 6.1 & 6.5 & 7.2 & 61 & 5.97 & 49.6 & 0.298 & 0.065 & 6.6 \\
\hline $\begin{array}{l}\text { 深度 } \\
(\mathrm{m})\end{array}$ & $\begin{array}{c}\mathrm{K}^{+} \\
(\mathrm{ppm})\end{array}$ & $\begin{array}{c}\mathrm{Ca}^{2+} \\
(\mathrm{ppm})\end{array}$ & $\begin{array}{c}\mathrm{Mg}^{2+} \\
(\mathrm{ppm})\end{array}$ & $\left(\begin{array}{c}\mathrm{Hd} \\
\mathrm{CaCO} \\
\mathrm{ppm}\end{array}\right)$ & $\begin{array}{c}\mathrm{Fe} \\
(\mathrm{ppm})\end{array}$ & $\begin{array}{c}\mathrm{Cl}^{-} \\
(\mathrm{ppm})\end{array}$ & $\begin{array}{l}\mathrm{SO}_{4}^{2-} \\
(\mathrm{ppm})\end{array}$ & $\begin{array}{c}\mathrm{SiO}_{2} \\
(\mathrm{ppm})\end{array}$ & $\begin{array}{c}\mathrm{COD} \\
\left(\mathrm{O}_{2} \mathrm{ppm}\right)\end{array}$ \\
\hline 流入水 $\mathrm{A}$ & 5.4 & 3.62 & 1.25 & 14. 1 & 0.050 & 6.8 & 1.5 & 26.0 & 0.64 \\
\hline 0 & 5.4 & 3.62 & 1.08 & 13.5 & 0.015 & 6.9 & 1.2 & 23.5 & 0.95 \\
\hline 1 & 5.7 & 3.67 & 1.05 & 13.5 & 0.036 & 7.0 & 1.0 & 22.0 & 0.80 \\
\hline 2 & 5.6 & 3.45 & 1. 19 & 13.5 & 0.023 & 6.9 & 1.3 & 23. 0 & 0.86 \\
\hline 3 & 5.3 & 3.88 & 0.92 & 13.5 & 0.043 & 7.0 & 1.3 & 22.3 & 1.08 \\
\hline 4 & 5.3 & 4. 27 & 0.83 & 14.1 & 0.084 & 7.2 & 1.6 & 22.8 & 1.18 \\
\hline 5 & 5.5 & 4.01 & 1.07 & 14.4 & 0.044 & 7.2 & 1.5 & 22.8 & 1.02 \\
\hline 6 & 5.4 & 4.05 & 1.23 & 15.2 & 0.029 & 7.1 & 1.8 & 21.3 & 0.76 \\
\hline
\end{tabular}

（注）湖表水測定時の気温は $19.5^{\circ} \mathrm{C}$ であつた

ほとんど過飽和の状熊を続ける。この期間は同時に $\mathrm{pH}$ 值も高く，基歴生産量の大きいこ とを物語る。なお，4 月上旬より 7 月上旬にがて，2４m の深度に著しい過飽和（最高 170\%）の水塊を見出すここができる.この期間においては，この層は $\mathrm{pH}$ が 8 以上（最高 8.5）字す.この時期は植物性プランクトンの繁殖期に当り，したがつてこの㞒は光合 成のもつとも盛えな所と考えられる(小久保, 1960). この問題の風を境にして酸素飽和 度, $\mathrm{pH}$ 值が逆転する、いま，さらに検討を加えるために植物性プランクトンの繁殖期に 当る 5 月の資料袁 2 にかかげておこう.これから溶存酸秦量と $\mathrm{pH}$ この相関図を描いて みると，図8のように雨者間に順相関の成立が見られる。相関係数は＋0.924で1，6 水準

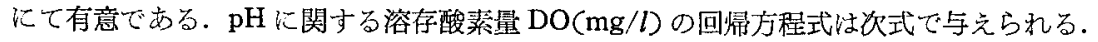

$$
\mathrm{DO}=4.4 \mathrm{pH}-22.3
$$

またおなじ 5 月の凟料を用いて溶存酸素量と $\mathrm{pH} 4.3$ アルカリ度との相関関係を検討し 


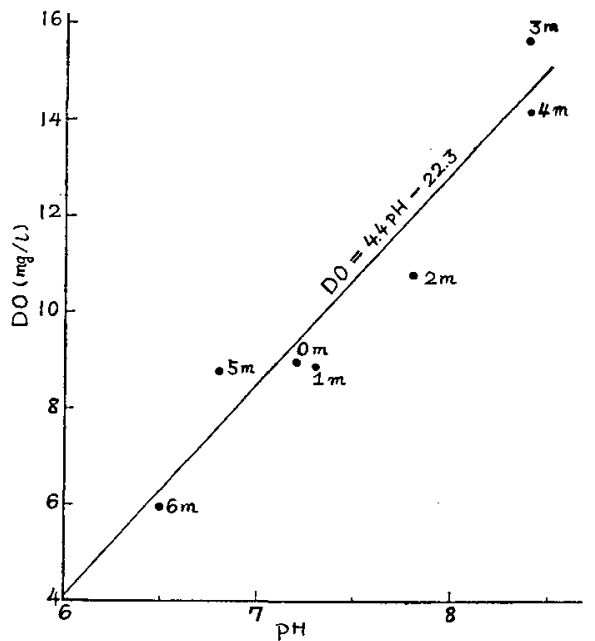

図 8. 溶存酸蒵量と $\mathrm{pH}$ との相関図 (1964. V-20)

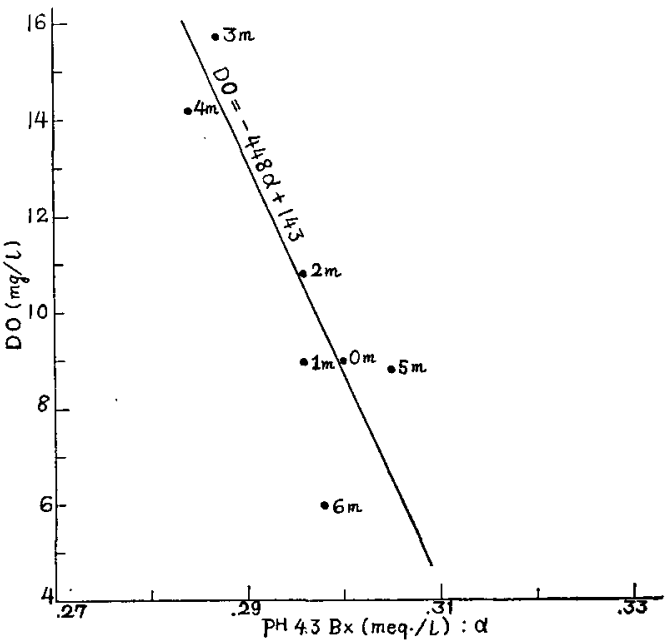

図 9. 溶存酸素量と $\mathrm{pH} 4.3 \mathrm{Bx}$ との相関図 (1964. V-20)

てみる. 図9のように相関係数は -0.921 で高度に有意である。 $\mathrm{pH} 4.3$ アルカリ度 $\alpha$ $(\mathrm{meq} / l)$ に対する溶存酸菜量 $\mathrm{DO}(\mathrm{mg} / l)$ の回帰方程式は $\mathrm{DO}=-448 \alpha+143$ にて与年え 
れる.これらの多くの事実から，この湖沼の溶存酸素量は植物性プランタトンの光合成と 密接な関係をるつことが明らかになる。

ここには一々挙げなかつたが，水質なとかから推して，この湖沼は調和湖沼標式の富栄養 型であることが判明した。

\section{4. 結 言}

山形市「沼の辺」貯水池についてとれまで得られた知見をまとめるとつぎのようになる.

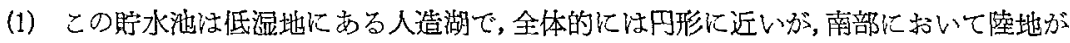
突出して肢節量は 1.27 である. また湖岸線の長さは $926 \mathrm{~m}$ ，最大深度は $7.40 \mathrm{~m}$ である.

（2）湖表水の化学成分定当量濃度で比較すると $\left.\left.\left.\mathrm{Na}^{+}\right\rangle \mathrm{Ca}^{2+}\right\rangle \mathrm{K}^{+}, \mathrm{HCO}_{3}{ }^{-}>\mathrm{SO}_{4}{ }^{2-}\right\rangle \mathrm{Cl}^{-}$の関

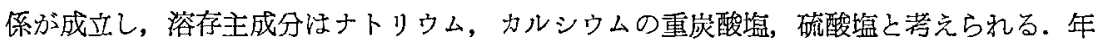
間を通して pH4.3, アルカり度 $\alpha$ と $\mathrm{Ca}^{2+}$ 漕度 $\left[\mathrm{Ca}^{2+}\right]$ の間には $\alpha=0.060\left[\mathrm{Ca}^{2+}\right]+0.095$ が成り立つ。

（3）水温の垂直分布の年変化から，この湖治の 1 年をつぎのような時期に区分できる.

4 月下旬 8 月下旬 夏季停滞期

8 月下旬 10 月上旬 夏季部分循器期

10月上旬～12月下旬 秋季完全循環期

1 月上旬 3 月上旬 水結期

3 月上旬 4 月中旬 春季半停滞期

（4） 4 月上旬加 7 月上旬にかけて，2〜 $4 \mathrm{~m}$ の深度に溶存酸素量の著しい過飽和の水塊 が発達する。同時にとの圈の $\mathrm{pH}$ 注 8 以上で基礎生産の高いとと定示す。

(5) この湖沼以調和湖沼標式の富栄養型に属する.

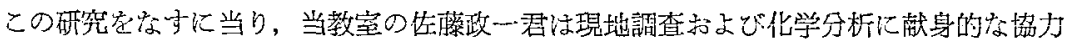
究惜しまなかつた．また，当学部化学研究会員の学生諸君も実験に協力した，記して謝意 を表する次第である。(1965年 5 月 8 日，日本陸水学会第30回大会にて講演)

\section{参考 文 献}

Hutchinson G. E. : “A Treatise on Limnology", Vol. 1, 439 440, John Wiley and Sons, Inc., New York, 1957.

加藤武雄，米地文夫：鳥ノ海火口湖の湖沼学的研究. 東北地理，17，1，36４0，1965. 加藤武雄：一切経「五色泊」に関する三，三の湖沼学的知兄. 1965年 4 月24日東北地理学 会春季学術大会にて講演.

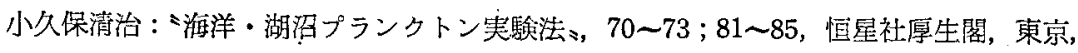
1960. 
村下敏夫: ‘地下水学要論 \$, 130 134, 昭晃堂, 東京, 1963.

西条八束：“湖沼調查法s, 古今書院, 東京, 1957.

総理府：昭和32年総理府令第14号, 官報 No.9074, 1957.

\section{S U M M A R Y}

"Numa-no-be" is the artificial lake in the suburbs of Yamagata City and was constructed during the period 1943 1947 for agricultural use. The present studies were made chiefly from the hydrochemical standpoint with special reference to the seasonal variation of the quality-of-water.

(1) The morphometrical data of this lake are summarized as follows:

\begin{tabular}{lcc} 
Surface area & $:$ & $4.21 \times 10^{4} \mathrm{~m}^{2}$ \\
\multicolumn{2}{l}{ Length of shore line : } & $926 \mathrm{~m}$ \\
Maximum depth & $:$ & $7.40 \mathrm{~m}$ \\
Mean depth & $:$ & $4.90 \mathrm{~m}$ \\
Volume & $:$ & $2.06 \times 10^{5} \mathrm{~m}^{3}$ \\
Shore development & $:$ & 1.27
\end{tabular}

(2) Regarding the chemical constituents of surface water, the content decreases in the order : $\mathrm{HCO}_{3}{ }^{-}>\mathrm{SO}_{4}{ }^{2-}>\mathrm{Cl}-$ for anion and $\mathrm{Na}^{+}>\mathrm{Ca}^{2+}>\mathrm{K}^{+}$for cation. Throughout a year, linear relationship is found to exist between pH4. 3 alkalinity and calcium ion concentration.

(3) The observation of thermal stratification reveals that this lake belongs to Hutchinson's "second-class lake".

(4) In summer stagnation period, $\mathrm{pH}$ rises to a maximum in the metalimnion and then declines. This phenomenon is associated with the high photosynthetic productivity of this lake.

(5) This lake belongs to the eurotrophic lake of the harmonic type.

(著者: 加藤武雄, 山形大学教育学部化学教室, 山形市; Takeo $\mathrm{K}_{\mathrm{AT}} \overrightarrow{\mathrm{O}}$, Chemical Laboratory, Faculty of Education, Yamagata University, Yamagata City) 